\title{
TRAUMATIC EXPERIENCES IN EKA KURNIAWAN'S NOVEL SEPERTI DENDAM, RINDU HARUS DIBAYAR TUNTAS
}

\author{
Endang Sartika \\ State Islamic Institute of Purwokerto \\ sartika_endang@iainpurwokerto.ac.id
}

Article accepted : May - 06-2020

Revised article: November - 11 - 2020

Approved article: November - 16 - 2020

\begin{abstract}
The emergence of trauma study with the publication of Cathy Caruth's Unclaimed Experience: Trauma, Narrative, and History have gained significant interest in analyzing traumatic experiences in literary works. Literary trauma is seen as the media and alternative to read the wound and trauma through narration and fiction in the form of an anxiety plot. This study aims to analyze the traumatic experiences in Eka Kurniawan's novel entitled Seperti Dendam, Rindu Harus Dibayar Tuntas. This research is descriptive qualitative in nature. The objects of this research are the traumatic events and experiences in Kurniawan's novel. The data were collected by note taking and highlighting the relevant traumatic event and analyzed using the concept of trauma and memory of Cathy Caruth. The result shows that the characters in this novel respond to trauma differently such as having intrusive thoughts, re-experiencing the trauma through flashbacks and dreams, avoidance, and having negative feelings and moods. The novel shows that the sociocultural environment can become the greatest source of trauma as well as offer the healing process for the traumatized through compassion and understanding. The characters' traumatic experience is narrated by the unknown godlike narrator. Through the portrayal of the characters, Kurniawan reveals how pain, suffering, and traumatic experiences lead the characters to gain high self-esteem, self-knowledge, and philosophical understanding of social reality.
\end{abstract}

Key Words: Traumatic experiences, literary trauma, Eka Kurniawan's novel

\begin{abstract}
Abstrak
Munculnya studi trauma dengan publikasi Cathy Caruth's Unclaimed Experience: Trauma, Narrative, and History telah menarik banyak penelitian untuk menganalisis pengalaman traumatis dalam karya sastra. Sastra traumatik dipandang sebagai media dan alternatif untuk membaca luka dan trauma melalui narasi dan fiksi dalam bentuk alur traumatik. Penelitian ini bertujuan untuk menganalisis pengalaman traumatic dalam novel Eka Kurniawan "Seperti Dendam, Rindu Harus Dibayar Tuntas". Penelitian ini merupakan penelitian deskriptif kualitatif dengan pengalaman traumatis dalam novel karya Eka Kurniawan sebagai objeknya. Data dikumpulkan menggunakan note taking dan highlighting peristiwa traumatis yang relevan dan dianalisis menggunakan konsep trauma dan memori Cathy Caruth. Hasil analisis menunjukkan bahwa karakter dalam novel ini menunjukkan respons berbeda terhadap trauma seperti pemikiran intrusive, mengalami kembali kejadian traumatis dalam bentuk flashback atau mimpi buruk, menghindari segala hal yang bisa mengingatkan mereka akan kejadian traumatis serta memiliki perasaan dan pikiran buruk. Novel ini menunjukkan bahwa lingkungan sosial-budaya dapat menjadi sumber trauma terbesar sekaligus menawarkan proses penyembuhan bagi korban melalui belas kasih dan pengertian. Pengalaman traumatis para karakter tersebut dinarasikan oleh unknown narrator. Melalui penggambaran karakter, Kurniawan menunjukkan bagaimana rasa sakit, penderitaan dan pengalaman traumatis dapat membuat seorang individu memiliki pemahaman filosofis tentang diri dan realitas sosial.
\end{abstract}

Kata Kunci: pengalaman trauma, sastra traumatik, novel Eka Kurniawan 


\section{INTRODUCTION}

Human life is an interesting phenomenon despite all the complexities and problems they experience including dreadful traumatic experiences such as accidents, the death of the loved one, abuses, or natural disasters. Without any warnings, those traumatic events can happen to every person when they are not mentally prepared and those can also trigger people to experience trauma. According to the American Psychiatric Association, trauma or traumatic neurosis referred to a response to an event "outside the range of usual human experience" including human and natural catastrophes (Caruth, 1995). That event or events can be a confrontation to actual or threatened death, severe injury, or sexual abuse. Trauma can happen to someone experiencing or witnessing the traumatic event directly or indirectly.

The term trauma is originated from the Greek word for "wound" which refers to a serious injury to a person's body. According to the Merriam-Webster Dictionary, trauma means a very difficult or unpleasant experience that causes someone to have mental or emotional problems usually for a long time (Trauma / Definition of Trauma by MerriamWebster, 2020). Later, trauma not only refers to a physical wound but also a psychological wound. A psychologist Robert Jay Lifton on "Survivor Experience and Traumatic Syndrome" insinuates that trauma happens when the survivor had faced death. He argues that encountering death instigates individual psy- chological disturbances because it forces individuals to reassess the final ultimate of life (Lifton, 1995: 131). To be stumbled upon death encounter means encountering something resistant and incomprehensible in the man's mind which eventually causes disintegration of the psyche and individual inner catastrophe, what he called 'castration anxiety'. Thus, in trauma, there is something enigmatic, catastrophic, and extreme that is incomprehensible upon man's mind causing splitting of self's integration and dissociation. In other words, trauma can be an individual's response to something that is too shocking and overwhelming that the man's mind is unable to grasp which eventually falls into the psyche and cause disintegration, distortion, and rupture.

Trauma and its theory itself had been discussed, reviewed, and pondered since its first emergence in the late nineteenth century and was first gained its significant role in the postWorld War I studies (Balaev, 2014: 4). The fields of trauma studies also had emerged from psychiatry to literary studies. Literature as the representation of human life offers multiple perspectives that allow readers to reflect on a variety of human responses to an overwhelming experience in the form of an anxiety plot as in fiction, movie, or poetry. Vickroy (2014) argues that fictions depict the many avenues for expressing the voices of trauma through the survivor's narrative. It describes the conditions and characteristics of the traumatic experience. Though trauma is usually accompanied by silence, literature, or fiction, in this sense offers 
the possibilities to read the wound and the wounded. Thus, in fiction trauma represents the unspeakable wound of human life through traumatic narration.

Literature as the representation of human life in which the author is part of the society, thus, presents a work of art as hyperrealist. Literature, then, cannot be separated from the representation of human life. It is interesting to observe literary works in terms of seeing them as the representation of life. Likewise in this article, the researcher tries to analyze novels that represent the living conditions of society, especially in Indonesia, regarding social issues and the psychological impacts caused by violence and injustice.

In the Indonesian context, trauma can be found in realist literary works that focus more on the traumatic experiences triggered by political instabilities and disturbances. Although as a present generation, we don't have the experience of trauma directly as the Indonesian facing the mass killing of 1965 (known as G30S PKI) or the reformation riot in 1998. We are affected by and are indirectly responsible for those traumatic events because we grow up with those histories to borrow Morris-Suzuki's term, we are "an implicated community" which may not be responsible for such acts of aggression in the sense of having caused them, but we are "implicated" in them, in the sense that they cause us (McGregor, 2013). In this case, authors also indirectly feel that they are part of the "implicated community" who responsible for the traumatic event or events, and thus influence the authors to write the traumatic experience in fiction to represent the history of violence in Indonesia. After all "literature becomes a traumatic escape" (Salam, 2020). For instance, trauma caused by the colonization as portrayed by Annelis and Nyai Ontosoroh in Pramudya A. Toer's Bumi Manusia, trauma caused by the mass killing of 1965 as experienced by Srintil in Ahmad Tohari's Ronggeng Dukuh Paruk and caused by the 1998 incident as experienced by Laut Biru in Laela S. Chudory's Laut Bercerita.

Apart from the several authors above, Eka Kurniawan is also one of the Indonesian writers who built his works on the traumatic discourse. He is acclaimed to be the pioneer of Indonesian social realist writers. He published several literary works that illustrate the social reality of Indonesian society including traumatic experience, sexual abuse, and domestic violence caused by social and political injustice. His first novel, Cantik Itu Luka (Beauty is a Wound: 2002) tells about a prostitute name Dewi Ayu who experiences trauma during the Indonesian independent movement which left a scar on her life and influence her children's life. His second novel Lelaki Harimau (Man Tiger: 2004) also sets in a traumatic experience where the protagonist's (Margio) family experiencing domestic abuse because of poverty. Those two novels are notable Indonesian literary works translated into many languages and received many awards locally and internationally for its vivid illustration of Indonesian society. It also at- 
tracts researchers to analyze his works through many perspectives as in Arifin (2019) studying The existential epidemic in Lelaki Harimau as Eka Kurniawan's symbolic Strategy, Wahyuningsyih (2018) analyzed the characters needs in the novel Lelaki $\mathrm{Ha}$ rimau using Abraham Maslow's humanistic psychology perspective, Yulianti (2007) analyzed psychoanalysis in Cantik Itu Luka, and Ayu (2019) analyzing the cultural terms in English Translation of Cantik Itu Luka.

This study, however, aims to analyze the traumatic experience of the characters in Eka Kurniawan's third novel Seperti Dendam, Rindu Harus Dibayar Tuntas (2014) or Vengeance is Mine, All Others Pay Cash (2017) in English. Set in the modern society of Indonesia, the characters in She does not speak and is completely silent because of that trauma.this novel witness and experience traumatic events that change their lives and the way of looking at their lives. This novel tells a story about a boy (Ajo Kawir) who becomes impotent after being forced to witness a brutal rape done by police toward a madwoman (Rona Merah). Ajo Kawir's impotency eventually affects his whole life including his marriage life with Iteung, a girl who also experiencing trauma after being molested by her homeroom teacher. The plot of this novel develops in the traumatic context and the journey of Ajo Kawir in dealing with his impotency (trauma).

This research uses descriptive qualitative research in an attempt to understand and make sense of phenomena from the researcher's perspective. Merriam \& Grenier (2019: 6) defines qualitative research as a research method characterized by the search for meaning and understanding in which putting the researcher as the primary instrument of data collection and analysis. This research particularly combines phenomenology and narrative analysis to analyze the traumatic experiences in a literary text. The phenomenological study uses to analyze the inner experience of the characters in the novel. Meanwhile, narrative analysis is used to analyze the story in the novel in terms of the characters' internal thoughts.

The object of this research is traumatic experiences in Eka Kurniawan's novel Seperti Dendam, Rindu Harus Dibalas Tuntas. The data were collected by note taking and highlighting the traumatic experiences found in the novel. The data then were classified based on the characters and the traumatic events they experienced. The analysis of this research will be done in three steps. First, this research will describe the traumatic condition experienced by the characters in the novel. Then, it will explain the factors of trauma experienced by the characters and how it affects their life. Besides, the analysis portrays how the trauma experienced by the narrated characters in this novel.

This novel is interesting to discuss because it is structured in the context of trauma which is based on social injustice and the state apparatus' repression toward the people. Different from postcolonial literary studies which are 
mostly experienced by a group of people or society and how it changes their life as a nation, this novel is focusing more on the individual traumatic experience and the way experience shapes the character as an individual. It is also supported by the fact that the trend of literary trauma becomes more prevalent in today's society. Take as an example a very sensitive 2013 Korean film Hope about a child suffers from Post-traumatic stress disorder (PTSD) after being kidnapped, beaten, and raped by a stranger, this film gains worldwide attention for its vivid illustration of the traumatic experience implicated to the victim. This film illustrates that traumatic experiences do not only affect the victim but also the family and society. Another example is the Indonesian movie 27 Steps of May (2018) which tells a story about a young girl (May) a victim of rape that shut her door for the world for 8 years. These two movies are just an example of how trauma and traumatic experiences are very familiar in human daily life. Thus, analyzing traumatic literature is interesting because it can be used to understand the suffering of intense trauma and to reflect the actual reality happening in society.

By the increasing number of cases of sexual violence, rape, and pedophilia, Eka Kurniawan's Novel Seperti Dendam, Rindu Harus Dibayar Tuntas is very relevant and relatable to the many cases of trauma in Indonesia caused by sexual violations. Though many readers said that this novel is erotic and vulgar, and not supposed to be read by the read- er under 18 years old, this novel succeeds in portraying the sad reality of Indonesian society particularly in illustrating the traumatic experiences caused by rape and molestation. Therefore, this study is intended to analyze the character's traumatic experience in Kurniawan's novel Seperti Dendam, Rindu Harus Dibayar Tuntas.

This research draws upon Cathy Caruth's concept of trauma and memory to unveil the characters' psychological disturbance after experiencing trauma. Caruth proposes that

"trauma is a response, sometimes delayed, to an overwhelming event or events, which takes the form of repeated, intrusive hallucinations, dreams, thoughts or behaviors stemming from the event, along with numbing that may have begun during or after the experience, and possibly also increased arousal to (and avoidance of) stimuli recalling the event". (Caruth, 1995: 4).

Trauma is a record of past traumatic memory of events which means people have not fully understood the feeling of being traumatized when the event occurs, but they will have it after the shock and pass a few moments or years. So, traumatic memory is a delayed response after someone experiencing trauma. From the above definition, it can be understood that the victim may respond to trauma differently. Being traumatized will often show traumatic symptoms such as often having hallucinations based on the traumatic events they experience and will appear in the form of dreams, memories, or thoughts. The victims can also become numb to things, feel excessively anx- 
ious, or trying to avoid things that can stimulate them to remember the traumatic events. In line with Caruth, Maria Roots in Vickroy (2014: 133) also argue that victims of trauma may respond to trauma in an unsympathetic environment such as "egocentrisms, quickness to anger, social and emotional withdrawal, rumination or shutting down".

In line with those arguments, the traumatized may show traumatic symptoms as categorized by the American Psychiatric Association as follows: a) Intrusion or reexperiencing. The victims of trauma may experience intrusive thoughts such as repeated hallucinations which can be flashbacks, involuntary memories, or distressing dreams. They may experience nightmares and wake up with fear and tremble as if they are reexperiencing the trauma. Besides, the flashbacks of the traumatic event may appear, and remind them when they are triggered by something related to that event; b) Avoidance. The response toward trauma may include avoiding people, places, or situations that can remind them of their traumatic events. Their gesture such as being silent, shutting down, and staying away from others and society can be a sign to resist thinking, remembering, and talking about that event; c) Negative Cognition and Mood. Someone experiencing trauma may have steadily negative thoughts, feelings, and distorted beliefs about themself or others. They may have continuously the symptoms of fear, horror, anger, guilt, or shame; d) Arousal. Traumatic symptoms include hyper-arousal and reactive symptoms such as quickness to anger, easily irritate, behaving recklessly, or in a selfdestructive way, so they may also have a problem sleeping.

Based on the premise that the victim of trauma may respond to traumatic events differently, so this research aims to find out the characters' response to their traumatic experiences in the novel. Therefore, this study will treat the literary text as the representation of actual human life with its physiological aspects of traumatic experiences.

\section{FINDING AND DISCUSSION}

The finding and discussion of this research are divided into three parts. First, it discusses the traumatic experiences in the novel seen from the traumatic symptoms as proposed by Caruth and the American Psychiatric Association. Second, it presents the cause of trauma and how the characters deal with their trauma. Third, it discusses how the narration of trauma in the novel.

Kurniawan's novel Seperti Dendam, Rindu Harus Dibalas Tuntas sets in traumatic context and tragic events. The trauma is experienced both by the hero and the heroine of this novel as well as another character that causes the hero's trauma. The causes and consequences of the trauma they experienced are varied based on their psychological ability to deal with their trauma. The characters illustrate the traumatic symptoms such as quickness to anger, depression, and hallucinations after having a dreadful 
experience. Caruth (1995) suggests that the victims of trauma may react to the traumatic events differently including having intrusive thoughts, avoidance, hyper-arousal, and negative cognitions and feeling. The feeling of hopelessness, excessive anxiety, sadness, and distress have accompanied the traumatized. Moreover, traumatic responses may include shame, doubt, guilt, and may destroy important belief in one's safety or view of oneself as decent, strong, and autonomous (Vickroy, 2014)

\section{Traumatic Experiences in Seperti Dendam,}

\section{Rindu Harus Dibalas Tuntas}

Kurniawan's novel Seperti Dendam, Rin$d u$ Harus Dibalas Tuntas is built in the traumatic discourse. This novel tells the story of a young boy, Ajo Kawir, who has trauma after witnessing a brutal rape. It causes his impotency which leads him to be a different person. Because his trauma develops with the traumatized characters, it changes in total the ways of him reassessing his survival, being, and thinking. Ajo Kawir, the hero as well as the main character in the novel, experiences trauma when he and his best friend named Tokek peeked at Rona Merah, a madwoman who lives alone in her house far from the other houses after Tokek persuaded Ajo to go to her house, then one night, their teenage libido has driven them off. Before, they used to peek at The Head Village while having sex with his new wife, to read erotic comics, or to masturbate while watching model pictures in the bathroom. However, that night was different. Ajo Kawir didn't have any idea what will happen if Tokek persuaded him to go to Rona Merah's house. At a stroke of midnight, they saw something unusual which was two policemen came to Rona Merah's house and raped her brutally. The novel assumes that the polices had been coming to rape her regularly because they had the house key. When they were watching the scene while shivering, Ajo Kawir slipped and caused noises, a few minutes later he was seized by them. He was being forced to stand next to the table where Rona Merah was still laying naked being raped brutally by them, with a pistol in his forehead as described in the following quotation:

"The muzzle felt cold against his skin and out of the corner of his eye, he could see the pistol shining. And that was how, with his body trembling violently, this time from fear, with a pale face and quivering lips, unable to make a sound, Ajo Kawir was forced to watch those two polices take turns raping Rona Merah." (Kurniawan, 2017: 28)

Ajo Kawir is encountering death and witnessing sexual abuse. These have disrupted his psyche too deeply, as Lifton argues that encountering death instigates individual psychological disturbances because it forces them to reassess the final ultimate of life (Lifton, 1995: 131). As Lifton's phrase, he is experiencing "castration anxiety" as narrated that "his body is trembling violently", "fear", "pale face and quivering lips, unable to make a sound". There is something lodged too deeply in his mind that the brutality of raping and encountering death. 
He experiences inner catastrophe and self disintegration, or something that he cannot understand, that is unconsciously rupturing his psyche and causing his impotency, "the boy's penis was curled up as small as it could get, shriveled and practically collapsed in on itself". According to the American Psychiatric Association, in severe cases, trauma causes significant problems including mental and physical health problems such as showing impulsive behavior or physical manifestations like tremors or headaches. In the Ajo Kawir case, the traumatic event causes a significant problem towards his physical health in the manifestation of impotency.

Ajo Kawir and Tokek develop their first symptom of trauma in the form of negative cognition and mood. As young boys of 12 or 13 years old, the traumatic event they have gone through must be incomprehensible upon their understanding. Someone experiencing trauma may have constantly negative thoughts and feelings including fear, horror, anger, guilt, or shame (American Psychiatric Association). After finding out that Ajo Kawir was impotent, he tried everything to make his dick wake up. Once he rubbed the chopped chili pepper on his genitals, another time he purposefully let his pennies get stung by bees. His dick still won't stand up even after he read a lot of erotic books or looked at twelve naked whores standing in front of him. He also tried to chop his genitals with a hatchet as his response toward his helplessness. He felt fear, shame, helplessness, and uselessness because of his impotency. That makes him afraid about life. When he met a girl he loved Iteung, this traumatic symptom has been haunting him throughout his life particularly. He hesitates to accept her love because he is afraid that he can't make her happy. The fear of his impotency proves to be true because he cannot satisfy his wife's sexual needs, then his wife has an affair with other men. After this incident, Ajo Kawir becomes more furious and brutal. He even killed someone and imprisoned for 10 years. As for Tokek, he always feels guilty and responsible for what happened to his best friend, even though he is not experiencing the traumatic event directly but he is the one and the only person who witnesses Ajo Kawir's traumatic experience. Tokek also feels helpless because he cannot do anything to help his friend nor he can cure him. The only thing he can do is to always be there for Ajo Kawir, becomes his best friend and comrade. He will accompany Ajo Kawir to fight whenever he cannot control his anger. He even promises not to touch or marry any woman before Ajo Kawir's impotency heal.

Another traumatic response that usually displays by the victim of trauma is Avoidance. The traumatized people may avoid everything that can remind them of the traumatic experience. They may avoid thinking, remembering, or talking about their traumatic experience. Being silent, shutting down, or staying away from social are common responses for the victim of trauma. In this novel, Ajo Kawir and Tokek also try to avoid talking about that traumatic inci- 
dent. They do not want to remember that terrible night, nor want anyone to know about it. Seeing Ajo Kawir being depressed with his impotency makes Tokek wonder whether he should tell his father because he thinks that someone should know in which to help his friend. In the end, he only tells his father that Ajo Kawir is impotent without saying what makes him impotent. It is narrated that Ajo Kawir is crying when Tokek's Father, Iwan Angsa, examines his dick. Then, he begged not to tell his parents about it. They just want to silence and shut down the bad memory. When Iwan Angsa asks what exactly happened, both of them just stare at each other and say nothing but "we don't know". They try to avoid talking about the traumatic event as illustrated in the following narration:

"He didn't want Iwan Angsa to know what they'd done. He didn't want to add on to all their problems. He didn't want to talk about how the two policemen had gone to Rona Merah's house and raped that crazy woman." (Kurniawan, 2017: 32).

Arousal is another symptom display by Ajo Kawir as his response to trauma. It is a strong negative reaction of something caused by the victim's incomprehensible to deal with the depression and excessive feeling caused by the traumatic event, such as quickness to anger, easily irritate, behaving recklessly or in a self-destructive way (American Psychiatric Association). Ajo Kawir becomes excessively aggressive and easily irritated by something as ordinary as seeing a group of boys smoking in front of him. Whenever he feels distress cause of his impotency, "he will cause trouble by fighting in the streets, in the movie theatre, at the swimming pool, and on the soccer field" (p.37) of course accompanied by Tokek. As the result, they get kicked out of school, reenroll to another school, and get kicked out again. He will be irritated whenever seeing a man teasing a woman. He becomes furious whenever he knows there is injustice toward women. For instance, Aji cut Mr. Lebe's ear to teach him a lesson because he coerces a young widow, even he does not know this widow but he has the feeling to do that to help the woman. This must-have reminded him of Rona Merah's suffering. His belief about there is no justice creates him to fight dreadfully. As he is impotent, he thinks that his life is meaningless and useless, and therefore, he is not afraid to fight until death. This feeling of uselessness and meaningless is a common response of trauma victims. When people have a traumatic event, they will have distorted beliefs in themselves or others.

The victims of trauma may re-experience the traumatic including hallucination, flashbacks, or dreams. These haunt the victim through intrusive thought which can appear in nightmares. They will wake up with fear and tremble as if they are re-experiencing the trauma. Iteung, Ajo Kawir's wife, is one of the characters in the novel who re-experiences her trauma in a distressing dream. Iteung had experienced molestation when she was in junior high school by her homeroom teacher named 
Mr. Toto. He got used to asking her to help him with some small insignificant tasks, then sit beside her, put his shoulder close to hers, and his fingers would touch, squeeze her breasts naughtily while she was completing her tasks. This happened until one day that she experiences a traumatic event because Mr. Toto hugged her close from behind while she was sitting on his lap in the "Guidance Office".

"His left hand was holding the little girl's breast and the other hand was feeling around under her skirt...Iteung could feel something poking out insistently, touching her buttocks...then she felt something wet and sticky...Iteung quickly stood up, freeing herself, and looked back at the dark black genitals dropping on the chair" (Kurniawan, 2017: 162)

Since that day, Iteung experiences trauma and psychological complex, having a strong feeling of anxiety but at the same time feeling of pleasure wanting to have sex. She responses to her trauma in the form of a haunted dream as if she re-experiences that tragic event.

"whenever she dreamed about that man, she would wake up dripping with sweat and her body would be hot, yet she'd be shivering. Her fingers would be trembling, her jaw would be clenched, but she could her teeth chattering. At the same time, she was wet. Slimy. Flooded. As if she longed for that blunt piece of urgent flesh" (Kurniawan, 2017: 162)

She would wake up gasping, sweating and her face would be pale. The trauma that she experienced on that day leave something deeply in her mind and unconsciously drive her sexual desire every time she dreams and thinks about Mr. Toto. She becomes a sex addict that she cannot resist her desire even after marrying Ajo Kawir. In other words, her trauma causes her to experience psychoneurosis or neurotic as a result of the repression of unacceptable desires. The traumatic event will eventually be repeated in flashbacks every time she thinks and dreams of that man.

The other character who experiences trauma is Rona Merah. She is the madwoman who plays a big role in Ajo Kawir's impotency. Rona Merah's traumatic experience is narrated vaguely in the novel that none knows exactly what happened to her. She was portrayed as a "madwoman who often berserk". Some people said that Rona Merah was witnessing her husband being shot by a troop of soldiers in front of her eyes while having dinner, some said while the couple was in their bedroom making love.

However, all versions of the story mentioned that Agus Klobot, Rona Merah's husband was shot to death in front of her (p.13). Few weeks after that incident, "Rona Merah sat in front of her husband's corpse, hugging her knees and weeping continuously, her clothes splattered with his blood. Then, after a while, she started babbling and grinning to herself" (p.14). After that day, Rona Merah became insane and silent. Here, she experiences "inner catastrophe" as argued by Hartman (1995: 367) that in trauma, something "falls" into the psyche and causes it to "split". Witnessing her husband being shot in front of her eyes must be dreadfully extreme 
and catastrophic which is incomprehensible in her mind that eventually causing splitting of herself integration and dissociation.

That event has ruptured and distorted her psyche that she becomes insane and hysterics. It is just said that her psyche response in such a way as she experiences castration anxiety. Thus, Rona Merah reacts to her trauma in silence, she completely shuts down her door and withdraws emotionally and socially from the world. Her insanity can be seen as a real response to her dreadful experience.

Based on the above analysis, the traumatic experiences in Kurniawan's novel can be seen in the following table:
Many factors can influence the traumatic experiences including environment, cultural values, and social interaction. Maria Root and Laura S. Brown in Vickroy (2014: 130) argue that "the socio-cultural contexts that shape individual identities may also shape how a survivor understands a traumatic experience". That argument suggests that individual comprehension of their thought, feelings, and experiences is formed and cultivated within its environment, cultural values, and social interaction. This environment is also one of the most influential factors in shaping individual personality, behavior, and character including mode of being and self-understanding. It induces the caus-

Table 1. Traumatic Experiences in the novel Seperti Dendam Rindu Harus Dibalas Tuntas

\begin{tabular}{|c|c|c|c|}
\hline No & Characters & Traumatic Experiences & Symptoms \\
\hline 1 & Ajo Kawir & $\begin{array}{l}\text { Ajo Kawir experiences trauma while peeking at Rona } \\
\text { Merah being raped brutally by two polices in her house } \\
\text { one night. He was being forced to witness the molesta- } \\
\text { tion in front of his eyes with a pistol in his forehead } \\
\text { when he was twelve or thirteen years old. From that } \\
\text { night onward, Ajo Kawir is impotent and his impoten- } \\
\text { cy affecting many aspects of his life. (pp. } 27-30 \text { ) }\end{array}$ & $\begin{array}{l}\text { Hyperarousal- Neg- } \\
\text { ativer Cognitions } \\
\text { and r mood- } \\
\text { avoidance }\end{array}$ \\
\hline 2 & Iteung & $\begin{array}{l}\text { Iteung experiences trauma while being molested by his } \\
\text { homeroom teacher when she was in junior high school. } \\
\text { Since that day, she used to have a nightmare about that } \\
\text { molestation and wake up with fear, sweating, shiver- } \\
\text { ing, and trembling but at the same time desire to have } \\
\text { sex. (pp. 160-165) }\end{array}$ & $\begin{array}{l}\text { Intrusion-Dream- } \\
\text { flashback }\end{array}$ \\
\hline 3 & Rona Merah & $\begin{array}{l}\text { Rona Merah experiences trauma while having dinner } \\
\text { with her late husband when suddenly an army force } \\
\text { came and shoot her husband in front of her eyes. For } \\
\text { weeks after his death, Rona Merah sits in front of his } \\
\text { corpse crying and became insane. (pp. 13-14) }\end{array}$ & $\begin{array}{l}\text { Avoidance } \\
\text { (Silencing and shut- } \\
\text { ting down) }\end{array}$ \\
\hline 4 & Tokek & Witnessing Ajo Kawir's traumatic experience directly & $\begin{array}{l}\text { Avoidance- } \\
\text { Negative cognitions } \\
\text { and mood }\end{array}$ \\
\hline
\end{tabular}

The Factors of Traumatic Experiences and

How the Characters Deal with Their Trauma es and effects of traumatic experiences. Thus, the understanding of the social-cultural environment within the context of trauma is re- 
quired in understanding the individual traumatic experience.

Furthermore, it is also necessary to understand that the social-cultural environment shapes the characters' personality and selfunderstanding. Even though two boys, Ajo Kawir and his best friend Tokek, are witnessing the same traumatic events, their responses to that event are distinct. Ajo Kawir unconsciously becomes impotent meanwhile Tokek does not. Therefore, it can be said that every individual can respond differently to the same traumatic event as Caruth's argument that the same traumatic event may or may not traumatize everyone equally (Caruth, 1995), because Ajo Kawir and Tokek have a different character and personality nurture from their parents and society. Both live in the same neighborhood but their parents come from a different class of society. Ajo Kawir is the son of a library officer, so he must have been taught moral and religious values which made him think unconsciously that the brutality of two polices raping the madwoman should not be done meanwhile, Tokek is the son of an ex-bandit which of course has a different style in nurturing moral value to his son.

In the novel, it is narrated that Ajo Kawir and Tokek used to go to surau (a kind of mosque) to study how to pray. Even after peeked at The Headman Village making love to his wife, Ajo Kawir took shower and prayed tahajjud hoping his sin may be forgiven but Tokek did not have that sense. Then, in his childhood, Ajo Kawir used to read some comics. Strangely his comics were about heaven and hell which eventually have influenced his way of thinking that he doesn't want to go to hell. Hence, when Tokek asked him to peek at The Headman Village again, he said that he did not want to go to hell because he was afraid that his dick would be bitten by a pussy with teeth. Based on this narration, Ajo Kawir and Tokek have different responses to the same traumatic event. Ajo Kawir has distinct moral and religious values deep in his mind meanwhile, Tokek doesn't. Therefore, the brutality of raping Rona Merah and the event of a gun pressed in his head have made Aji's responses different. He is not only witnessing something that is too shocking in his mind while also encountering death, but he was also being forced to rape her after they finished their wrongdoing. When he saw Rona Merah's genital reddish folds and crack, he must think of the pussy with teeth and unconsciously rupturing his psyche and caused his impotency.

After experiencing that dreadful night, Ajo Kawir developed a different way of looking at his life. He had tried many ways to cure his impotency but it wouldn't have stood up even twelve naked whores in front of him, and they had tried every trick in the book to get it up for him. As a teenager of fifteen years old, that condition of course led to his frustration. He became fearless to anything, brutal, and likes to fight. Whenever he saw an inappropriate manner done by a man or a group of men to a woman, he will fight them dreadfully. He once cut 
Pak Lebe's left ear because he had raped the young widow who rents his house. Ajo Kawir was furious with this kind of man attitude, though he has no relation to the young widow he was reminded of Rona Merah and all her suffering. Therefore, he developed to be a man who will respect a woman and defend the vulnerable woman with all his power. Only after he had killed someone out of his frustration and stay in the prison for 10 years, Ajo Kawir found resolution and tranquility. He had accepted his impotency as bliss. This character development was influenced by the environment that has nurtured him since his childhood.

Despite playing a significant role in shaping man's character and behavior, the sociocultural environment can also become the greatest force toward traumatic experiences. Vickroy (2014: 130) argues that "the environment of social interaction and cultural values can be the sources of the traumatic experiences". The traumatic experiences from the socio-cultural environment can cause the most damaging and devastating experiences to the psyche.

Kurniawan in his novel also portrays that the socio-cultural environment is the greatest source of trauma. The police and the soldiers, who are supposed to protect and offer shelters for the people, in this novel are described as an apparatus that caused trauma by committing various criminal acts. The soldiers are narrated as the sources of Rona Merah's traumatic experiences as they shot her husband in front of her eyes meanwhile, the two police were not protecting Rona Merah after became insane, rather they continuously raped her without anyone knowing. The police criminal acts are also the greatest source of Ajo Kawir's impotency meanwhile, in Iteung's case, instead of becoming a role model for his students and a person where the students sought knowledge, her teacher became a person who caused trauma by molesting his student in the young age.

This novel suggests that the police, soldiers, and teacher despite being "home" offering security, protection, and refuge for the individual. This can be the source of "vulnerability", the place where individuals become alienated within a larger social framework. Rona Merah is not only traumatized person by the brutality of the soldiers killing her husband in front of her eyes and the police continuously raping her, but she is also being alienated in the society. She is being forced to silence and being insane. The society around her is reluctant and careless toward the incident. This is narrated that week after the shooting incident none wants to approach her house, to take care of her husband's body because the society does not smell anything since the house is far from the neighborhood, nor even cares when she is found dead in his husband graveyard the night after the raping incident. They inadvertently have forced Rona Merah to be silent by not offering any help or even care.

The socio-cultural environment not only forms the circumstances out of how trauma has 
been created but also provides or refuses the needed support for healing (Vickroy, 2014: 132). Societies, communities, or families propagate the alienation felt by the traumatized because they may want to preserve stability and protect themselves from vulnerability, avoid what survivors have experienced, and prevent survivors from sharing their experience with others or sometimes it is also willing to sacrifice the survivors for other goals (Vickroy, 2014: 131-132).

The socio-cultural environment may become a source of trauma. On the other hand, it may also present the healing process. This place can silence the voices of the traumatized, but it also offers an alternative way to communicate their suffering, especially through literature. Ajo Kawir can deal with his trauma because he is surrounded by some people who always support him. Besides being his best friend who plays a big role in his impotency, Tokek also gives compassion and understanding to him. He is a person who always understands Ajo Kawir's frustration about his condition. He will listen to Ajo Kawir, accompanying him to fight with naughty boys, find solutions to cure his impotency, and even swear that he will not touch or marry any girl before Ajo Kawir recovers from his impotency. Iwan Angsa and Wa Sami is both Tokek's parent who also provides a refuge for Ajo Kawir to deal with his trauma. After being impotent, Ajo Kawir often fights with anyone and is dropped out from school to school. Here, the role of Iwan Angsa and
Wa Sami is accommodating him in their house, offering shelter and security for the vulnerable when his biological parents give up to take care of him. Then, the role of Ki Jempes, a blind man with whom he shared 10 years of his life in prison, is helping him to deal with his trauma. He has taught him a hard lesson in life so he finds wisdom and tranquility after release from prison. This novel does not leave the traumatized alone but also offers compassionate friends and family to help them with the healing process.

\section{The Narration of the Traumatic Experiences in Eka Kurniawan's Novel}

According to Hartman (1995: 367), the traumatic experience is "one that cannot be made entirely conscious, in the sense of being fully retrieved or communicated without distortion". There is a gap between the trauma and the unspeakable experience; the gap to utter the unrepresentable event into something that can be comprehended by the human's mind. Hartman (1995: 540) argues that in trauma, there is "something being lodged too deeply in the psyche as epiphany word and image rupturing the symbolic order". Literary works had made it possible to read the wound and the unspeakable experience through narration. For example, several scenes portraying traumatic experience in Shakespeare's Henry IV Part I after he came back from war (Hunt, 2010: 15; Bušková, 2013), John Milton's Paradise Lost, Virginia Woolf's Mrs. Dalloway, William Faulkner's Light in August (Abubakar, 2017), and 
Margaret Atwood's Cat's Eye (Heidarizadeh, 2015).

Kurniawan in Seperti Dendam, Rindu Harus Dibalas Tuntas narrates the main character's traumatic experience and wound through the unknown narrator. Kurniawan communicates his main character's intense suffering (which he, himself, the main character is unable to speak) by creating the unknown narrator who seemingly knows and understands the inner mind and psychological complex of the protagonists. Then, this can indicate he/she is the god who witnesses the events and understands their utmost pain.

The unknown narrator in describing Ajo Kawir traumatic experience partly shares his task with other characters in the novel like Iwan Angsa as in the opening line of the novel:

"Only guys who can't get a hard fight with no fear of death," Iwan Angsa once said about Ajo Kawir. He was one of the small handful of people who knew that Ajo Kawir's penis couldn't stand up. He'd seen it, nestling like a newly hatched baby bird-curled into itself, looking hungry and cold." (Kurniawan, 2017: 1)

Though Iwan Ansa does not narrate the traumatic event which caused Ajo Kawir's impotency. In the novel, he is one character who knows that Ajo Kawir is impotent and how his impotency affects his life afterward. Yet, the character who knows exactly what happened to Ajo Kawir is Tokek as his best friend. The happening traumatic event at that night is narrated clearly by Tokek as he has seen the scene when two polices forced Ajo Kawir to witness their brutality raping by pressing a gun in his head as in the following narration:

"Tokek, who at first didn't know what had happened, came out of the bushes and crept back to the window. From there he saw Ajo Kawir, standing like a living corpse beside the table. Tokek wondered whether he should go inside and help Ajo Kawir, but when he saw the pistol pressed to his friend's head, he stayed put, overwhelmed. The thought crossed his mind to go tell someone what was going on, but after he mulled it over for a moment, he decided that the whole mess would just get more complicated if he did, and made up his mind to wait." (Kurniawan, 2017, p. 28)

In this part, Tokek works as the narrator who voices the wound of the traumatized when Ajo Kawir himself is unable to speak to anyone else about what happened to him because there is a gap to utter the enigmatic experience through words. Therefore, the narration of this traumatic event is narrated by someone else who witnesses it directly. This helps the traumatized voicing his wound and unspeakable pain. From Tokek's narration, we understand how the dreadful experience that Ajo Kawir has been gone through because he was standing like a living corpse facing an unbearable scene while at the same time encountering death, like what the overwhelmed Tokek when he saw the pistol pressed to his friend's head.

Meanwhile, Iteung's traumatic experience is narrated vividly by herself by the memory and dream. The narration of her trauma is described by the seemingly godlike narrator who witnesses the traumatic event and understands 
the inner self of the traumatized as in the following narration:

\begin{abstract}
"Iteung will always remember that time-when Mr. Toto's hands would fondle and squeeze them. Iteung would almost squeal, but she held it in. her pencil would fall from her trembling hand. And when Mr. Toto holding her close from behind. The man was sitting on a chair, embracing her, and Iteung was sitting on his lap. His left hand was holding the little girl's breast and the other hand was feeling around under her skirt...Iteung could feel something poking out insistently, touching her buttocks...then she felt something wet and sticky...Iteung quickly stood up, freeing herself, and looked back at the dark black genitals dropping on the chair. Iteung felt a pain in the crack between her legs. She tried to walk like usual, but it hurt there." (Kurniawan, 2017: 162)
\end{abstract}

In this narration, it can be seen that Kurniawan as the writer plays the role of the godlike narrator. He recounts vividly the traumatic event as well as the traumatized inner feeling by portraying them through his character's memory and dream as in whenever she dreams about that man or in she will always remember that day.

Different from the narration of Ajo Kawir and Iteung, the traumatic experience of Rona Merah is obscure because none exactly know what happened to her. Here, she never talks about what happened and whoever shot her husband. Her trauma is told by some people with different versions. Kurniawan does not play his role as a godlike narrator in portraying Rona Merah's traumatic experience. Instead, he borrows the narration ambiguously from many versions by an article reported in the paper, or what some people said, that can be seen in the following narration:

"A squadron (years later they realized that it was a troop of soldiers) came to that house. An article in the paper reported that Agus Klobot had been armed and had fought back before they shot him dead. But some people said the soldiers stormed the house, shooting blindly, and that Agus Klobot was riddled with bullets, right in front of Rona Merah as they were eating dinner. His blood splashed across his wife's face-and it wasn't just blood that sprayed out of the bullet holes, so did his stomach worms and the rice he'd just eaten. Others said the shooting occurred when the couple was in their bedroom making love. The soldiers made Agus Klobot finish his last orgasm in heaven. But the version that made the most sense had just one sniper carrying out the execution, shooting from a hiding place behind some trees when Agus Klobot opened the window. In any case, in all versions of the story, Agus Klobot was shot to death right before his wife's." (Kurniawan, 2017: 13)

This novel portrays the characters' traumatic experiences through a different style of narration. Hence, literary style provides the multiple perspectives and nuances of expressing the inexpressible and unspeakable experiences through narrative and fiction. By the words, readers can understand the wounds and the manifold of the individual's responses to an enigma. Through literature, the traumatized can communicate their profound suffering. Literature, in other words, plays the role of the alternative instrument to read the wound and listen to the trauma. Bušková (2013) argued that narrative expression can alleviate the suffering of the traumatized by reconstructing the autobiographical memory which brings imme- 
diate relief to the traumatized.

\section{CONCLUSION}

Trauma as an unrepresentable event relates to an extreme experience that is too shocking and overwhelming to be fully registered upon man's consciousness, offers the nuance of man's psychological experiences displaying the inner world of man relating to the social phenomenon. Literature has become the media to express those unrepresentable and unspeakable events in the form of anxiety plots that are influenced by pain, wound, and trauma as in Eka Kurniawan's novel Seperti Dendam, Rindu Harus Dibalas Tuntas. In this novel, Kurniawan portrays the characters' traumatic experiences through different angles of narration.

This novel is set in an anxiety plot that focuses on the characters' profound suffering and how their trauma affects their lives as well as how they cope with their trauma. They are the hero Ajo Kawir; the heroine Iteung, and the character that plays the important role toward the hero's trauma named Rona Merah as well as the witness of the hero's trauma named Tokek. These characters respond to traumatic experiences differently. Some responses illustrated by the characters in this novel are avoidance, intrusion, arousal, and negative thought and mood. The characters have been haunted by their trauma in the form of flashbacks and distressing thoughts as experienced by Iteung. In response to their trauma, they felt hopeless, shame, afraid, anger, and distress. Some characters react to it in destructive ways such as quickness to anger and easily nuisance as experienced by Ajo Kawir. As the victims, they try to avoid thinking, remembering, or talking about their trauma or things that can remind them of their trauma. They prefer to be silent and shut their door to the world. They choose to embrace their trauma and grow with it. After all, they all are merely human.

The socio-cultural environment plays an important role in the characters' traumatic experiences. It shapes the characters' personalities and nurtures their social and moral value. Therefore, this environment can make every character face the trauma differently. The novel also depicts that the environment can become the greatest source of trauma as well as present the healing process through compassion and understanding from family, friends, or society.

The traumatic events in this novel are dominated narrating by the unknown character playing the role of the godlike narrator who witnesses and understands the traumatized utmost pain. Those are narrated by using the witness's eyes, sometimes using the vivid memory of traumatized people, and using the vague narration from many sources when none witnesses the traumatic events. It is believed that narrating traumatic experiences can help traumatized people and alleviate their profound suffering.

\section{REFERENCES}

Abubakar, S. (2017). Art as Narrative: Recounting Trauma through Literature. IRA- 
Poetika : Jurnal Ilmu Sastra

Vol. 8 No. 2, December 2020
DOI 10.22146/poetika.55895

ISSN 2338-5383 (print) ; 2503-4642 (online)
International Journal of Management \& Social Sciences (ISSN 2455-2267), 8(1), 118-123. DOI: http:// dx.doi.org/10.21013/jmss.v8.n1.p13.

Arifin, Moch. Zaenul. (2019). Lelaki Harimau: Wabah Eksistensial Sebagai Strategi simbolis Eka Kurniawan. Aksara, 31 (2), DOI:10.29255/aksara.v3li2.372.177-178 Accessed 21/4/ 2020.

Ayu, Panglipuring Tyas. (2019). An Analysis of Cultural Terms in Eka Kurniawan's English Traslation of Cantik Itu Luka. BA Project. Yogyakarta: Sanata Dharma University.

Balaev, Michele. (2014). Literary Trauma Theory Reconsidered. In Michele Balaev (ed), Contemporary Approaches in Trauma Literary Theory, (pp.1-12). London: Palgrave Macmillan.

Bušková, Kristýna. (2013). The Role of Literature in Reconciling Trauma on Personal and Social Level. Bohemia Literaria, 2, 83 $-91$.

Caruth, Cathy. (1995). Introduction. In Cathy Caruth (Ed), Trauma: Explorations in Memory, (pp. 3-11). Baltimore: Johns Hopkins University Press.

Hartman, Geofrey H. (1995). On Traumatic Knowledge and Literary Studies. New Literary History, 26 (3) 537-563. http:// muse.jhu.edu/journals/

new_literary_history/

v026/26.3hratman.html Accessed $17 \mathrm{Au}$ gust 2019.

Heidarizadeh, Negin. (2015). The Significant Role of Trauma in Literature and Psychoanalysis. Procedia-Social and Behavioral Sciences, 192, 788-795 available online at www.sciencedirect.com Accessed 24 January 2019.

Kurniawan, Eka. (2014). Seperti Dendam, Rindu Harus Dibayar Tuntas. Jakarta: PT Gramedia Pustaka Utama.

Kurniawan, Eka. (2017). Vengeance is Mine, All Others Pay Cash. Translated by Annie Tucker. New Delhi: Speaking Tiger Publishing Pvt. Ltd.

Lifton, R. J. (1995). An Interview with Robert Jay Lifton. In Trauma: Explorations in Memory, (pp.128-147). Baltimore: Johns Hopkins University Press.

McGregor, Katherine E. (2013). Memory
Studies and Human Rights in Indonesia. Asian Studies Review, 37(3), 350-361, DOI: 10. 1080/10357823.2013.792782.

Merriam, Sharan B., \& Grenier, R. S. (2002). Qualitative Research in Practice. San Francisco: Jossey Bass.

Merriam-Webster Dictionary. (2020). Trauma / Definition of Trauma, Retrieved 17 November 2020, from https://www.merriamwebster.com/dictionary/trauma

Salam, Aprinus. (2020). Novel Indonesia Setelah 1998: Dari Sastra Traumatik Ke Sastra Heroik. SINTESIS. 6 (1), https://ejournal.usd.ac.id/index.php/sintesis/ article/view/2708 Accessed 11Agustus 2020.

Vickroy, Laurie. (2014). Voices of Survivors in Contemporary Fiction.In Michele Balaev (Ed). Contemporary Approaches in Trauma Literary Theory, (pp. 130-151). London: Palgrave Macmillan.

Wahyuningsyih, Sri Et.al. (2018). Gambaran Kebutuhan Dalam Lelali Harimau Karya Eka Kurniawan (Kajian Psikologi Humanistik Abraham Maslow). [BA Thesis]. Available online at http://eprints.unm.ac.id Accessed on 21 April 2020.

Yulianti, Yeni. (2007). Psikoanalisi dalam Cantik Itu Luka Karya Eka Kurniawan. SINTESIS, 5 (2), Oktober 2007 https:// www.usd.ac.id Accessed 21 April 2020. www.psychyatry.org on PTSD 